\title{
EFISIENSI TEKNIS PERKEBUNAN KARET RAKYAT DI SUMATERA SELATAN: ANALISIS TWO-STAGE BOOTSTRAP DEA
}

\author{
Technical Efficiency of Smallholders' Rubber in South Sumatra: \\ Two-Stage Bootstrap Analysis
}

\author{
Lina Fatayati SYARIFA*
}

\author{
Pusat Penelitian Karet, Jln Raya Palembang - Pangkalan Balai KM 29, Sembawa \\ Banyuasin 30593 Sumatera Selatan \\ *Email : lina_fsy@yahoo.com
}

Diterima : 3 Agustus 2020 / Disetujui : 14 November 2020

\begin{abstract}
Low productivity is a problem faced by smallholder rubber farmers in South Sumatra, Indonesia. This study aims to examine the efficiency level of production and identify the determinants of the efficiencies related to smallholder rubber production in Indonesia. A survey was carried out in South Sumatra, and 380 rubber farmers were selected using a multi-stage random sampling procedure. A non-parametric two-step bootstrap DEA was employed to estimate the level of technical efficiency and its determinants using crosssectional data. The findings showed that the mean bias corrected technical efficiency estimates were lower (0.764) than traditional DEA estimates (0.802). Nevertheless, the bias-corrected efficiency scores were still in the range of confidence interval, indicating that the conventional DEA efficiency scores were overestimated. The truncated regression results showed that the level of farming experience and the type of tapping system used significantly influence the technical efficiency of rubber farms.
\end{abstract}

Keywords : bootstrap DEA; efficiency; estimation model; production; smallholder's rubber

\begin{abstract}
Abstrak
Produktivitas karet yang rendah merupakan masalah yang dihadapi oleh petani karet rakyat di Sumatera Selatan, Indonesia. Penelitian ini bertujuan untuk mengkaji tingkat efisiensi produksi dan mengidentifikasi faktor-faktor (determinan) yang memengaruhi efisiensi yang terkait dengan produksi karet rakyat di Indonesia.
\end{abstract}

Kegiatan survei dilakukan di Sumatera Selatan, dengan menganalisis 380 petani sampel yang dipilih melalui prosedur pengambilan sampel acak bertingkat. Twostage bootstrap DEA digunakan untuk mengestimasi tingkat efisiensi teknis dan determinannya menggunakan data crosssectional. Hasil penelitian menunjukkan bahwa skor efisiensi teknis yang menggunakan bootstrap DEA rata-rata lebih rendah $(0,764)$ dibandingkan skor DEA konvensional $(0,802)$. Namun demikian, skor efisiensi yang dikoreksi bias (bootstrap DEA) masih dalam kisaran interval kepercayaan, yang menunjukkan bahwa skor efisiensi DEA konvensional terlalu tinggi. Hasil regresi terpotong (the truncated regression) menunjukkan bahwa pengalaman berkebun karet dan sistem sadap yang digunakan petani berpengaruh signifikan terhadap efisiensi teknis usaha tani karet.

Kata kunci: bootstrap DEA; efisiensi; karet rakyat; model estimasi; produksi

\section{PENDAHULUAN}

Sumatera Selatan memainkan peranan penting dalam perkembangan industri karet di Indonesia. Sumatera Selatan merupakan provinsi penghasil karet terbesar di Indonesia dengan luas areal 839 ribu ha yang menghasilkan produksi sebesar 864 ribu ton atau $28 \%$ dari produksi karet nasional (Dirjenbun, 2016). Pelabuhan Bom Baru, Palembang merupakan pelabuhan ekspor karet terbesar di Indonesia dengan volume 998.341 ton atau $37,6 \%$ dari ekspor karet di Indonesia. Dibandingkan provinsi lainnya, Sumatera Selatan juga merupakan 
pengolah bahan baku karet terbesar yang diolah di pabrik sebelum diekspor. Pada tahun 2016, Sumatera Selatan memiliki 27 pabrik karet remah dengan kapasitas pengolahan 1.648.288 ton per tahun. Sementara, total bahan baku karet yang tersedia adalah 989.903 ton, yang berarti pabrik masih beroperasi di bawah kapasitas terpasang (Dewan Karet Indonesia, 2017).

Perkebunan karet di Sumatera Selatan didominasi oleh perkebunan karet rakyat yang meliputi $93 \%$ dari total area karet dan menyumbang $94 \%$ dari total produksi di Sumatera Selatan. Sekitar 24\% dari total penduduk Sumatera Selatan terlibat dalam industri karet. Namun, produktivitas perkebunan rakyat masih jauh lebih rendah dibandingkan perkebunan besar. Pada tahun 2015, produktivitas perkebunan besar swasta mencapai sebesar $1.736 \mathrm{Kg} / \mathrm{ha}$, sementara perkebunan besar negara sebesar 1.697 $\mathrm{Kg} / \mathrm{ha}$, sedangkan karet rakyat hanya sebesar $1.302 \mathrm{Kg} / \mathrm{ha}$ (Kementerian Pertanian, 2016; BPS Provinsi Sumatera Selatan, 2017).

Pemerintah telah berupaya untuk meningkatkan produktivitas karet rakyat melalui proyek-proyek pengembangan karet rakyat seperti Proyek Perkebunan Inti Rakyat (PIR), Proyek Pengembangan Karet Rakyat (PPKR), Tree Crop Smallholder Development Projects (TCSDP), dan Tree Crop Smallholder Sector (TCSS). Namun peningkatan produktivitas karet masih berjalan lambat. Dikarenakan mayoritas petani karet di Sumatera Selatan memiliki produktivitas rendah, maka dalam banyak kasus pendapatan yang diperoleh petani kecil tidak cukup untuk memenuhi kebutuhan hidup, kecuali produktivitas ditingkatkan secara substansial. Peningkatan produktivitas karet rakyat bisa menjadi penggerak utama bagi pertumbuhan kesejahteraan dan pengentasan kemiskinan masyarakat. Maka perlu dirancang suatu strategi yang bisa diterapkan untuk memperbaiki tingkat produktivitas karet rakyat. Salah satu upaya yang secara signifikan memengaruhi produktivitas adalah alokasi dan penggunaan sumber daya yang lebih efisien (Tasman, 2008). Akan tetapi, upaya untuk memperbaiki produktivitas harus didukung oleh pengetahuan empiris yang kuat mengenai efisiensi teknis produksi dan alokasi sumber daya. Oleh karena itu, perlu dilakukan pengukuran tingkat efisiensi teknis dan identifikasi faktor-faktor penentu penyebab rendahnya produksi pada perkebunan karet rakyat. Tulisan ini bertujuan untuk menghitung tingkat efisiensi teknis perkebunan karet rakyat serta mengidentifikasi faktor-faktor yang memengaruhi efisiensi teknis di perkebunan karet rakyat di Sumatera Selatan.

Farrell (1957) menyatakan bahwa efisiensi teknis dapat diukur dengan mengestimasi model frontier. Fungsi produksi frontier menurut Farrell (1975) dapat dibagi menjadi teknik parametrik dan non-parametrik. Teknik non-parametrik lebih mudah digunakan dibandingkan dengan teknik parametrik. Pendekatan data envelopment analysis (DEA) adalah model non-parametrik yang paling populer digunakan dalam literatur. DEA tidak dapat memperkirakan faktor-faktor yang memengaruhi efisiensi teknis dan fungsi produksi perbatasan secara bersamaan. Oleh karena itu, pendekatan DEA dua tahap (two-stage DEA) biasanya digunakan dengan menggunakan model OLS/Tobit pada tahap kedua untuk mengestimasi model efisiensi (Banker \& Natarajan, 2008; Ray, 2004). Ali et al. (2016) menggunakan metode two-stage DEA dengan menggunakan analisis Tobit untuk mengestimasi efisiensi teknis dan faktor-faktor determinannya pada produksi karet di Pahang, Malaysia. Sementara Tijani et al. (2017) juga menggunakan metode two-stage DEA untuk mengestimasi tingkat efisiensi teknis dan faktor-faktor yang memengaruhinya dengan menggunakan analisis Tobit pada produksi sawit rakyat di Malaysia.

Namun, Simar \& Wilson (2007) menemukan kelemahan dari pendekatan DEA konvensional. Mereka menyatakan bahwa estimasi efisiensi yang didasarkan pada DEA konvensional secara serial dapat berkorelasi. Selanjutnya mereka memperkenalkan Model bootstrap DEA untuk mengatasi kelemahan tersebut. Model bootstrap DEA dapat memberikan hasil statistik yang lebih konsisten dibandingkan dengan pendekatan DEA konvensional. Model bootstrap DEA juga dapat memberikan pengukuran efisiensi yang dikoreksi dan interval kepercayaan (Toma et al., 2017). Selanjutnya, Simar \& Wilson (2007) memperkenalkan two stage-bootstrap 
$D E A$ untuk membuat kesimpulan statistik tentang dampak variabel kontekstual. Oleh karena itu, bootstrap DEA merupakan metode pengukuran yang paling banyak digunakan untuk mengukur tingkat efisiensi teknis antara lain, studi yang dilakukan oleh Emrouznejad et al. (2014); dan Toma et al. (2017). Metode ini dapat menghindari kerumitan dalam pendekatan parametrik dalam hal spesifikasi teknologi dan faktor distribusi.

\section{METODOLOGI}

\section{Metode Pengumpulan Data}

Penelitian ini dilakukan di perkebunan karet rakyat Provinsi Sumatera Selatan, yang merupakan provinsi penghasil karet terbesar di Indonesia. Penelitian ini menggunakan prosedur pengambilan sampel acak bertingkat dengan memilih 384 responden. Sebanyak 11 kabupaten penghasil karet terpilih secara purposive, yaitu Kabupaten Lahat, Musi Banyuasin, Musi Rawas, Muratara, Ogan Komering Ulu, OKU Timur, Ogan Komering Ilir, Ogan Ilir, Muara Enim, Pali, dan Prabumulih, dengan total populasi sebanyak 411.336 petani karet yang terlibat di perkebunan karet. Menurut Krejcie \& Morgan (1970) populasi sebanyak 1.000.000 dapat diwakili oleh 384 sampel. Dengan demikian, data penelitian ini dikumpulkan dari 384 responden yang dipilih secara acak sederhana melalui survei data cross sectional pada petani karet yang dilakukan dari November 2016 hingga Maret 2017. Namun karena ada data-data yang tidak lengkap dan tidak konsisten, maka penelitian ini hanya mengevaluasi sebanyak 380 sampel petani. Pengumpulan data cross sectional dilakukan menggunakan kuesioner terstruktur dan wawancara terhadap petani dengan mengambil data untuk tahun produksi 2015, meliputi data produksi dan input produksi (total weighted trees (TWT)), pupuk, herbisida, dan tenaga kerja).

Selain itu diambil juga data yang terdiri dari karakteristik sosial ekonomi petani yang meliputi: umur petani, jumlah anggota keluarga, tingkat pendidikan (skoring $0=$ tidak sekolah, $1=\mathrm{SD}, 2=\mathrm{SMP}$, 3= SMA, 4= Diploma/Universitas), akses penyuluhan $(0=$ tidak mendapat penyuluhan, 1= mendapat penyuluhan), lama pengalaman berkebun karet, sistem sadap yang digunakan (variabel dummy $0=$ sistem sadap selain $\mathrm{S} / 2 \mathrm{~d} 2,1=\mathrm{S} / 2 \mathrm{~d} 2$ ), dan adopsi bahan tanam (variable dummy $0=$ non-klonal, 1= klonal). Kemudian dilakukan pengumpulan data produksi dan input produksi yang digunakan oleh petani.

\section{Model Estimasi}

Data envelopment analysis (DEA) memperkirakan tingkat efisiensi teknis di bawah asumsi skala hasil konstan (CRS) dan asumsi skala hasil variabel (VRS). Model CRS dapat diterapkan ketika semua kebun karet beroperasi secara optimal. Kenyataan di lapangan, terdapat banyak kendala yang menghambat usaha tani karet untuk dapat efisien secara optimal seperti kurangnya pasokan input, kurangnya pengetahuan dan pengalaman petani terhadap teknologi karet, harga input yang berfluktuasi, masalah keuangan, hama, penyakit, dan cuaca. Dalam kondisi ini, model CRS tidak dapat diterapkan di kebun karet. Sebaliknya, model VRS dianggap lebih tepat untuk memperkirakan tingkat efisiensi teknis kebun karet karena menambahkan kendala konveksitas pada asumsi CRS dalam model DEA.

Mengikuti Halkos \& Tzeremes (2010), model VRS DEA yang diperkenalkan oleh Banker et al. (1984) ditentukan sebagai berikut:

$$
\widehat{\Psi}_{D E A}=\left(\begin{array}{cc}
(x, y) \in \mathfrak{R}_{+}^{p+q} \mid y \geq \sum_{i=1}^{n} \gamma_{i} Y_{i} ; x \geq \sum_{i=1}^{n} \gamma_{i} X_{i} \text { for }\left(\gamma_{1}, \ldots \gamma_{n}\right) \\
\text { s.t. } \sum_{i=1}^{n} \gamma_{i}=1: \gamma_{i} \geq 0, & i=1, \ldots . n
\end{array}\right)
$$


Simar \& Wilson (2007) berpendapat bahwa estimasi efisiensi DEA konvensional secara serial dapat berkorelasi. Kemudian, mereka mengusulkan prosedur bootstrap DEA untuk mengatasi keterbatasan DEA konvensional. Pada tahap pertama, mengikuti notasi Halkos \& Tzeremes (2010), estimasi bias bootstrap untuk estimator DEA $\hat{\theta}_{D E A}(x, y)$ adalah :

$$
B \hat{I} A S_{B}\left(\hat{\theta}_{D E A}(x, y)\right)=B^{-1} \sum_{b=1}^{B} \hat{\theta}_{D E A, b}^{*}(x, y)-\hat{\theta}(x, y)
$$

Dimana, $\hat{\theta}_{D E A}(x, y)$ adalah nilai bootstrap dan $B$ mewakili replikasi bootstrap. Jadi, penduga terkoreksi bias dari $\theta(\mathrm{x}, \mathrm{y})$ yaitu :

$$
\begin{aligned}
\hat{\hat{\theta}}_{D E A}(x, y) & =\hat{\theta}_{D E A}(x, y)-B \hat{I} A S_{B}\left(\hat{\theta}_{D E A}(x, y)\right) \\
& =2 \hat{\theta}_{D E A}(x, y)-B^{-1} \sum_{b-1}^{B} \hat{\theta}_{D E A, b}^{*}(x, y)
\end{aligned}
$$

Pada tahap kedua, mengikuti notasi Balcombe \& Latruffe (2008), digunakan model regresi terpotong (the truncated regression) sebagai berikut:

$$
\widehat{\hat{\theta}}_{i=} Z_{i} \beta+\varepsilon_{i} \geq 1
$$

Dimana $\hat{\hat{\theta}}_{i}$ adalah penilaian efisiensi teknis bootstrap DEA dari petani kei; $\beta$ adalah parameter yang tidak diketahui; dan $\boldsymbol{\varepsilon}_{\boldsymbol{i}}$ adalah variabel acak terpotong (the truncated normal random) yang diasumsikan terdistribusi normal $\mathrm{N}(0, \sigma 2)$ dengan pemotongan kiri pada $1-\mathrm{Zi} \beta$, dan $\mathrm{Zi}$ adalah faktor yang dapat memengaruhi efisiensi teknis. Program R dan paket FEAR (Wilson, 2009) serta software Stata13 digunakan untuk mengimplementasikan model twostage bootstrap DEA.

\section{HASIL DAN PEMBAHASAN}

\section{Karakteristik Sosial Ekonomi Petani}

Statistik karakteristik sosial ekonomi responden di wilayah studi disajikan pada Tabel 1. Data menunjukkan bahwa petani sampel memiliki usia rata-rata 44 tahun, dengan standar deviasi sebesar 10,58, menunjukkan umumnya petani masih dalam usia produktif. Sementara rumah tangga petani terdiri dari seorang suami, istri, dan anak-anak, dan terkadang ada anggota lain yang tinggal bersama mereka, sehingga rata-rata petani sampel terdiri atas
4 anggota keluarga, dengan standar deviasi sebesar 1,18 . Dengan usia produktif petani dan jumlah anggota keluarga yang cukup, diperkirakan kondisi ini akan memberi dukungan bagi petani agar semangat meningkatkan pengetahuan dan keterampilan dalam menerapkan teknik budidaya karet anjuran untuk meningkatkan efisiensi produksi. Hasil penelitian terdahulu, menyatakan bahwa jumlah anggota keluarga memiliki pengaruh yang signifikan terhadap peningkatan efisiensi. Semakin banyak anggota keluarga maka usaha tani akan semakin efisien, dikarenakan semakin banyak jumlah tenaga kerja keluarga yang digunakan untuk mengerjakan usaha tani (Aliyu et al., 2017).

Dilihat dari tingkat pendidikan, data menunjukkan bahwa $2 \%$ petani sampel belum pernah mendapatkan pendidikan formal; 37\% dari petani telah menyelesaikan sekolah dasar; 23\% menyelesaikan sekolah menengah pertama; 32\% menyelesaikan sekolah menengah atas, dan 6\% menyelesaikan pendidikan setingkat diploma/universitas. Semakin tinggi tingkat pendidikan diharapkan dapat meningkatkan efisiensi produksi karet di tingkat petani. Kittilertpaisan et al. (2016) dalam studinya menyatakan bahwa tingkat pendidikan petani dapat memberikan pengaruh yang signifikan dalam meningkatkan efisiensi teknis pada usaha tani.

Data menunjukkan hanya 36\% petani yang pernah menerima layanan penyuluhan perkebunan. Akses layanan penyuluhan yang tidak memadai merupakan kendala berat dalam upaya meningkatkan produktivitas karet. Fadzim et al. (2017), menyatakan bahwa faktor penyuluhan dan pelatihan petani memberikan efek yang siginifkan dalam meningkatkan efisiensi produksi. Meskipun penelitian yang dilakukan oleh Aliyu et al. 
Tabel 1. Statistik demografi dan karakteristik sosial ekonomi petani

Table 1. Demographic and socio-economic characteristics of farmers

\begin{tabular}{|c|c|c|c|c|c|}
\hline $\begin{array}{l}\text { Variabel } \\
\text { Variable }\end{array}$ & $\begin{array}{l}\text { Unit } \\
\text { Unit }\end{array}$ & $\begin{array}{l}\text { Min } \\
\text { Min }\end{array}$ & $\begin{array}{l}\text { Mak } \\
\operatorname{Max}\end{array}$ & $\begin{array}{l}\text { Rata-rata } \\
\text { Average }\end{array}$ & $\begin{array}{l}\text { Std. Deviasi } \\
\text { Std. Deviation }\end{array}$ \\
\hline Umur petani & Tahun & 18 & 71 & 43.58 & 10.58 \\
\hline Jumlah anggota keluarga & Jumlah & 2 & 8 & 3.51 & 1.18 \\
\hline Tingkat pendidikan petani & Skor & 0 & 4 & & \\
\hline $0=$ tidak ada pendidikan & & & & 0.02 & - \\
\hline $1=\mathrm{SD}$ & & & & 0.37 & - \\
\hline $2=\mathrm{SLTP}$ & & & & 0.23 & - \\
\hline $3=$ SLTA & & & & 0.32 & - \\
\hline $4=$ diploma/universitas & & & & 0.06 & - \\
\hline $\begin{array}{l}\text { Kunjungan penyuluh } \\
1=\text { mendapat } \\
\text { penyuluhan }\end{array}$ & Dummy & 0 & 1 & 0.36 & - \\
\hline $\begin{array}{l}0=\text { tidak mendapat peny } \\
\text { Pengalaman berkebun }\end{array}$ & & & & & \\
\hline karet & Tahun & 2 & 47 & 19.23 & 9.57 \\
\hline $\begin{array}{l}\text { Sistem sadap } \\
\qquad \begin{array}{l}1=\mathrm{S} / 2 \mathrm{~d} 2 \\
0=\text { selain } \mathrm{S} / 2 \mathrm{~d} 2\end{array}\end{array}$ & Dummy & 0 & 1 & 0.16 & - \\
\hline $\begin{array}{l}\text { Jenis bahan tanam } \\
\begin{aligned} 1 & =\text { klonal } \\
0 & =\text { non klonal }\end{aligned}\end{array}$ & Dummy & 0 & 1 & 0.49 & - \\
\hline
\end{tabular}

Sumber: Survei lapangan, 2016-2017

(2017) dan Mailena et al. (2014) menyatakan bahwa akses layanan penyuluhan tidak memberikan pengaruh terhadap tingkat efisiensi.

Hasil survey juga menyatakan bahwa petani responden sudah memiliki pengalaman berkebun karet rata-rata 19 tahun, yang menunjukkan bahwa petani sudah memiliki keterampilan yang memadai untuk menerapkan teknik budidaya yang benar. Terkait sistem penyadapan, baru sedikit sekali $(16 \%)$ responden yang telah menerapkan sistem penyadapan yang direkomendasikan $\mathrm{S} / 2$ d2. Koefisien sistem penyadapan dapat memberikan pengaruh yang positif terhadap peningkatan efisiensi teknis (Aliyu, 2017). Sementara jumlah responden yang mengadopsi tanaman karet klonal sebanyak 49\%. Menurut Haryanto et al., (2015), bahan tanam klonal memiliki pengaruh positif yang signifikan dalam meningkatkan efisiensi produksi.

\section{Estimasi Efisiensi Teknis}

Pada Tabel 2, hasil DEA konvensional dan DEA bootstrap dianalisis menggunakan asumsi VRS model. Hasil estimasi DEA tradisional menunjukkan bahwa hampir 9\% perkebunan karet benarbenar efisien. Hasil estimasi efisiensi teknis yang diestimasi menggunakan analisis DEA konvensional menunjukkan bahwa perkebunan karet rakyat beroperasi di antara tingkat efisiensi 0,4001 dan 1,0000, dengan skor efisiensi teknis rata-rata 0,802 . Berdasarkan Grabowski et al. (1990), skor efisiensi ini menunjukkan bahwa rata-rata perkebunan karet yang dianalisis dengan 
Tabel 2. Distribusi frekuensi skor efisiensi teknis menggunakan model DEA konvensional dan bootstrap DEA

Table 2. Frequency distribution of technical efficiency scores obtained using the traditional DEA and bootstrap DEA Model

\begin{tabular}{|c|c|c|c|c|}
\hline \multirow[t]{2}{*}{$\begin{array}{l}\text { Kelas Efficiency } \\
\text { Efficiency Class }\end{array}$} & \multicolumn{2}{|c|}{$\begin{array}{c}\text { DEA konvensional } \\
\text { Conventional DEA }\end{array}$} & \multicolumn{2}{|c|}{$\begin{array}{l}\text { Bootstrap DEA* } \\
\text { Bootstrap DEA* }\end{array}$} \\
\hline & $\begin{array}{l}\text { Jumlah kebun } \\
\text { Total farms } \\
\text { (n) }\end{array}$ & $\begin{array}{c}\text { Persentase } \\
\text { Percentage } \\
\quad(\%)\end{array}$ & $\begin{array}{l}\text { Jumlah kebun } \\
\text { Total farms } \\
\text { (n) }\end{array}$ & $\begin{array}{c}\text { Persentase } \\
\text { Percentage } \\
(\%)\end{array}$ \\
\hline$<0.2000$ & 0 & 0.0 & 0 & 0.0 \\
\hline $0.2001-0.3000$ & 0 & 0.0 & 0 & 0.0 \\
\hline $0.3001-0.4000$ & 0 & 0.0 & 0 & 0.0 \\
\hline $0.4001-0.5000$ & 4 & 1.1 & 9 & 2.4 \\
\hline $0.5001-0.6000$ & 28 & 7.4 & 38 & 10.0 \\
\hline 0.6001-0.7000 & 62 & 16.3 & 64 & 16.8 \\
\hline $0.7001-0.8000$ & 72 & 18.9 & 86 & 22.6 \\
\hline $0.8001-0.9000$ & 115 & 30.3 & 137 & 36.1 \\
\hline 0.9001-0.9999 & 66 & 17.4 & 46 & 12.1 \\
\hline 1.00 & 33 & 8.7 & 0 & 0.0 \\
\hline Total observasi & 380 & 100.0 & 380 & 100.0 \\
\hline \multicolumn{5}{|l|}{$\begin{array}{l}\text { Ringkasan } \\
\text { statistik }\end{array}$} \\
\hline Rata-rata & \multicolumn{2}{|c|}{0.802} & \multicolumn{2}{|c|}{0.764} \\
\hline Minimum & \multicolumn{2}{|c|}{0.458} & \multicolumn{2}{|c|}{0.440} \\
\hline Maksimum & \multicolumn{2}{|c|}{1.000} & \multicolumn{2}{|c|}{0.952} \\
\hline Standar Deviasi & \multicolumn{2}{|c|}{0.133} & \multicolumn{2}{|c|}{0.121} \\
\hline
\end{tabular}

Sumber : Hasil estimasi penulis

Keterangan : *B $=2000$ replikasi bootstrap

menggunakan metode DEA konvensional tidak sepenuhnya efisien karena rata-rata skor efisiensi teknis masih di bawah standar 0,820 .

Perkiraan skor efisiensi teknis sebesar 0,802 menunjukkan bahwa efisiensi usaha tani karet, hanya mencapai $80,2 \%$ dari potensi optimal. Sisanya sebesar 19,8\% dari efisiensi teknis tidak terealisasi, menunjukkan bahwa petani masih dapat meningkatkan produksi sekitar 19,8\% dengan menggunakan input yang ada, apabila petani dapat meningkatkan faktorfaktor determinan yang berpengaruh positif dan signifikan dalam peningkatan efisiensi. Dibandingkan dengan skor efisiensi ratarata, terdapat lebih dari $75 \%$ kebun petani (memiliki kelas efisiensi antara 0,7001 dan 1,0000), yang mendekati skor efisiensi teknis rata-rata. Sementara itu, sisanya
(25\%) kebun petani masih berada (kurang dari 0,7001) di bawah skor rata-rata.

Namun, setelah estimasi efisiensi teknis dari metode DEA konvensional diperbaiki dengan menggunakan prosedur bootstrap DEA, tidak ada kebun karet yang sepenuhnya efisien. Dari hasil analisis menggunakan model bias-dikoreksi (bootstrap DEA), kebun karet petani beroperasi antara kelas efisiensi 0,4001 dan 0,9999 , dengan skor efisiensi teknis berkisar antara 0,440 dan 0,952. Jika dibandingkan dengan skor DEA konvensional $(0,802)$, skor efisiensi kebun karet yang dianalisis menggunakan model koreksi bias (bootstrap DEA) turun menjadi 0,764. Ada variabilitas yang sedikit lebih rendah dalam skor efisiensi teknis setelah menggunakan bootstrap DEA. Hal ini ditunjukkan oleh deviasi standar yang lebih rendah $(0,121)$ 
dari efisiensi bootstrap DEA dibandingkan dengan deviasi standar $(0,133)$ dari DEA konvensional. Hasil penelitian ini sejalan dengan hasil penelitian Emrouznejad et al. (2014), yang mana pada penelitiannya terdahulu skor efisiensi kebun setelah menggunakan boostrap DEA menjadi turun dibandingkan skor efisiensi pada analisis DEA konvesional.

Ringkasan statistik interval kepercayaan pada 95\% disajikan pada Tabel 3. Data pada Tabel 3, menunjukkan bahwa skor efisiensi teknis bootstrap DEA masih berada dalam kisaran interval kepercayaan. Sementara skor efisiensi teknis DEA konvensional berada di luar kisaran interval kepercayaan, sehingga dinyatakan bias. Hubungan antara skor efisiensi teknis dari hasil analisis menggunakan Bootstrap DEA dan DEA konvensional juga dijelaskan pada Gambar 1.

Gambar 1 menunjukkan bahwa skor efisiensi yang dikoreksi bias menggunakan bootstrap DEA secara konsisten lebih rendah dari pada skor efisiensi DEA konvensional. Namun penggunaan bootstrap DEA tidak mengubah tren efisiensi DEA konvensional. Hasil ini membuktikan bahwa skor efisiensi teknis di bawah DEA konvensional terlalu tinggi dan berkorelasi.

\section{Estimasi Determinan Efisiensi Teknis}

Hasil estimasi efisiensi teknis menunjukkan bahwa kebun karet petani masih belum efisien dan perlu ditingkatkan. Oleh karena itu, perlu ditentukan faktorfaktor (determinan) yang memengaruhi inefisiensi usaha tani karet. Faktor-faktor tersebut dapat diestimasi pada tahap kedua model bootstrap DEA. Pada tahap kedua, skor inefisiensi teknis bootstrap DEA yang diperoleh pada tahap pertama, diregresikan terhadap karakteristik sosial ekonomi petani (determinan) dengan menggunakan metode regresi terpotong (the truncated regression model). Dalam mengestimasi dampak faktorfaktor sosial ekonomi pada estimasi efisiensi teknis bootstrap DEA, Simar \& Wilson (2007) berpendapat bahwa model regresi terpotong adalah regresi tahap kedua yang lebih cocok dibandingkan dengan model ordinary least square (OLS) dan Tobit. Pada penelitian ini, determinannya adalah umur petani, jumlah anggota keluarga, tingkat pendidikan, kunjungan penyuluhan, pengalaman berkebun karet, sistem sadap, dan bahan tanam.

Hasil regresi terpotong (the truncated regression) disajikan pada Tabel 4. Hasil analisis menunjukkan bahwa semua determinan negatif terhadap model inefisiensi teknis, yang menunjukkan bahwa faktor-faktor tersebut memiliki pengaruh positif untuk meningkatkan efisiensi teknis. Lebih lanjut, hasil penelitian menunjukkan bahwa faktor-faktor yang memiliki pengaruh paling signifikan untuk meningkatkan efisiensi adalah faktor pengalaman berkebun karet dan sistem sadap dengan tingkat signifikansi secara statistik masingmasing sebesar 1\% dan 10\%. Dalam kaitannya dengan efisiensi teknis, hasil analisis menunjukkan bahwa efisiensi produksi karet di Sumatera Selatan dapat ditingkatkan dengan meningkatkan /memperbaiki kedua faktor determinan tersebut.

Tabel 3. Ringkasan statistik interval kepercayaan dan bias

Table 3. Summary statistics of confidence interval and bias

\begin{tabular}{lccc}
\hline Ringkasan statistik & \multicolumn{2}{c}{ Tingkat kepercayaan pada 95\% } \\
Summary statistics & $\begin{array}{r}\text { Confidence interval at 95\% } \\
\text { Batas bawah }\end{array}$ & $\begin{array}{c}\text { Batas atas } \\
\text { Lpper bound }\end{array}$ & Bias \\
& 0.732 & 0.796 & Bias \\
\hline Rata-rata & 0.408 & 0.453 & 0.038 \\
Minimum & 0.940 & 0.996 & 0.052 \\
Maksimum & 0.115 & 0.132 & 0.031 \\
Standar Deviasi & & & \\
\hline
\end{tabular}

Sumber : Hasil estimasi penulis

Keterangan : * $\mathrm{B}=2000$ replikasi bootstrap 


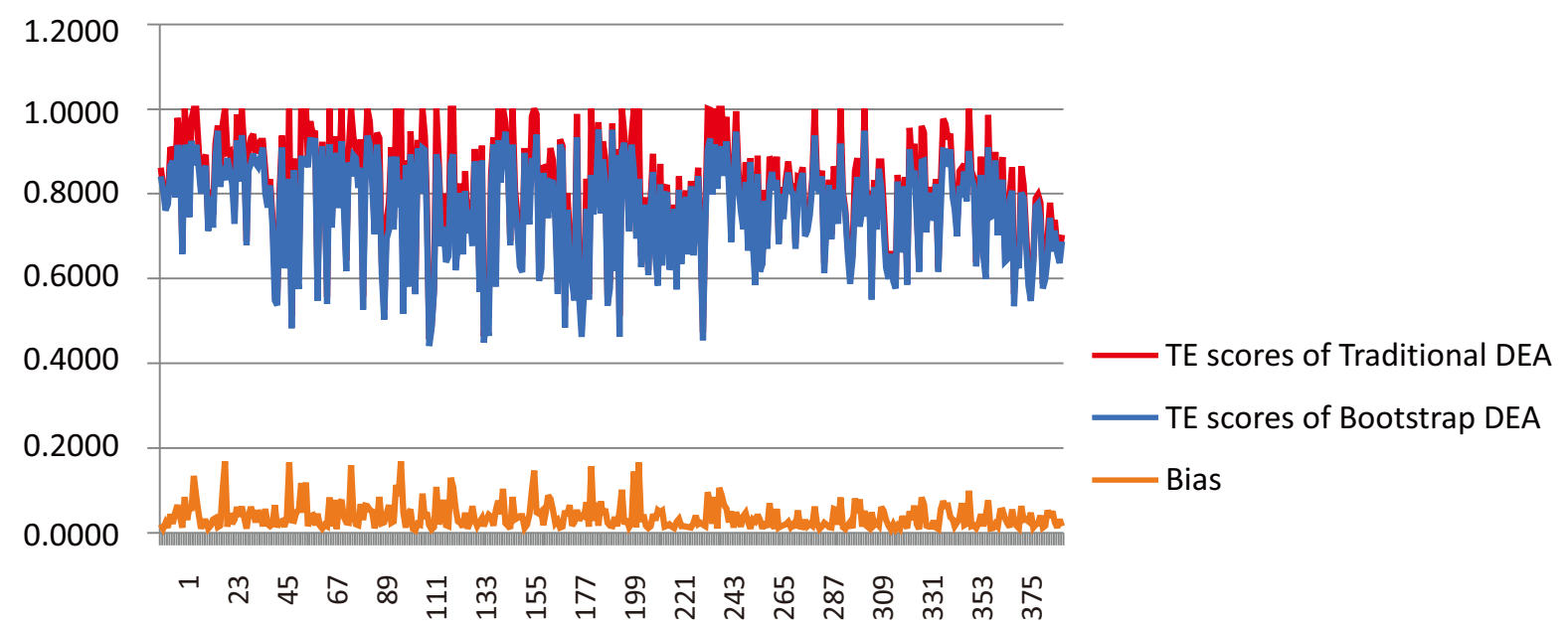

Gambar 1. Skor efisiensi teknis bootstrap DEA dan DEA konvensional

Figure 1. Technical efficiency scores of bootstrap and conventional DEA

Tabel 4. Model regresi terpotong inefisiensi teknis

Table 4. Truncated regression of technical inefficiency model

\begin{tabular}{|c|c|c|c|c|}
\hline $\begin{array}{c}\text { Variabel } \\
\text { Variables }\end{array}$ & $\begin{array}{l}\text { Parameter } \\
\text { Parameters }\end{array}$ & $\begin{array}{c}\text { Koefisien } \\
\text { Coefficients }\end{array}$ & $\begin{array}{c}\text { Standar kesalahan } \\
\text { Std. Error }\end{array}$ & $\begin{array}{c}\text { Rasio-t } \\
\text { t-ratio }\end{array}$ \\
\hline Umur petani & $\delta_{1}$ & -0.0004 & 0.0009 & -0.42 \\
\hline $\begin{array}{l}\text { Jumlah anggota } \\
\text { keluarga }\end{array}$ & $\delta^{2}$ & -0.0023 & 0.0059 & -0.39 \\
\hline Tingkat pendidikan & $\delta 3$ & -0.0080 & 0.0071 & -1.12 \\
\hline Penyuluhan & $\delta 4$ & -0.0126 & 0.0164 & -0.77 \\
\hline $\begin{array}{l}\text { Pengalaman } \\
\text { berkebun }\end{array}$ & $\delta 5$ & -0.0043 & 0.0011 & $-4.02^{* * *}$ \\
\hline $\begin{array}{l}\text { Sistem } \\
\text { penyadapan }\end{array}$ & $\delta 6$ & -0.0374 & 0.0205 & $-1.83^{*}$ \\
\hline Bahan tanam & $\delta 7$ & -0.0231 & 0.0142 & -1.62 \\
\hline Konstanta & $\delta_{0}$ & 0.3702 & 0.0387 & 9.56 \\
\hline
\end{tabular}

Sumber: Hasil estimasi penulis

\section{KESIMPULAN DAN SARAN}

Penelitian ini mengestimasi tingkat efisiensi produksi dan faktor-faktor yang memengaruhi inefisiensi teknis perkebunan karet rakyat di Indonesia. Hasil analisis regresi pada tahap pertama menunjukkan bahwa tingkat efisiensi teknis yang diperoleh dengan analisis DEA konvensional sebesar 0,802 . Sementara tingkat efisiensi teknis dari hasil analisis menggunakan Bootstrap DEA sebesar 0,764. Estimasi efisiensi teknis bootstrap DEA masih dalam kisaran interval kepercayaan, sementara estimasi skor efisiensi DEA konvensional dinyatakan bias karena terlalu tinggi dan berkorelasi. Namun demikian, dari hasil skor efisiensi teknis kedua metode tersebut dapat ditarik kesimpulan bahwa kebun karet petani di wilayah Sumatera Selatan masih belum efisien dan perlu dilakukan perbaikan, dikarenakan perkiraan efisiensi secara keseluruhan masih di bawah standar 0,820, mengindikasikan bahwa petani masih memiliki peluang untuk dapat meningkatkan produksi karet dengan input yang sudah ada apabila faktor-faktor yang memengaruhi infesiensi usaha tani karet dapat diperbaiki.

Pada regresi tahap kedua menggunakan regresi terpotong (the 
truncated regression) menunjukkan bahwa faktor pengalaman berkebun karet dan sistem sadap memiliki potensi yang signifikan untuk meningkatkan efisiensi teknis. Disarankan untuk meningkatkan pengetahuan petani mengenai teknologi penyadapan dengan menargetkan petani yang sudah berpengalaman sebagai peserta utama. Dengan demikian, pengetahuan tersebut dapat membantu petani dalam meningkatkan efisiensi produksi.

\section{DAFTAR PUSTAKA}

AAli, N., Ramli, N. A., \& Zulkipli, F. (2016). Estimating the efficiency of Pahang rubber smallholders using data envelopment analysis approach. Jurnal Teknologi, 78 (12-3), 147-153.

Aliyu, A., Latif, I. A., Shamsudin, M. N., \& Nawi, N. M. (2017). Factors affecting technical efficiency of rubber smallholders in Negeri Sembilan, Malaysia. Journal of Agricultural Science, 9(5), 226-232.

Balcombe, K., \& Latruffe, L. (2008). An application of the DEA double bootstrap to examine sources of efficiency in Bangladesh rice farming. Applied Economics, 40(15), 19191925 . d o i : 10.1080/ 00036840600905282 .

Banker, D. R., Charnes, A., \& Cooper, W. W. (1984). Models for estimation of technical and scale inefficiencies in data envelopment analysis. Manage Sci, $30, \quad 1078-1092$. doi: $10.1287 /$ mnsc.30.9.1078.

Banker, R. D., \& Natarajan, R. (2008). Evaluating contextual variables affecting productivity, Operation Research. 56, 48-58. doi: 10.1287/opre. 1070.0460 .

[BPS] Badan Pusat Statistika Provinsi Sumatera Selatan. (2017). Provinsi Sumatera Selatan dalam Angka (Sumatera Selatan Province in Figure) 2016. Palembang: Badan Pusat Statistik Sumatera Selatan. ISSN: 0215-2010.
Dewan Karet Indonesia. 2017. Data Industri Karet Indonesia. Jakarta.

[Dirjenbun] Direktorat Jenderal Perkebunan. (2016). Tree crop estate statistics of Indonesia (statistik perkebunan Indonesia), Rubber (karet) 2015-2017. Jakarta: Direktorat Jenderal Perkebunan.

Emrouznejad, A., Banker, R., Doraisamy, S. M., \& Arabi, B. (2014). Recent development in data envelepment analysis and its applications. Proceedings of the 12th International Conference of DEA. Kuala Lumpur, Malaysia. pp 362-368.

Fadzim, W. R., Aziz, M. I. A, \& Jalil, A. Z. A. (2017). Determinant of technical efficiency of cocoa farmers in Malaysia. International Journal of Supply and Chain Management, 6(1), 254-258.

Farrell, M. J. (1957). The measurement of productive efficiency. Journal of the Royal Statistical Society, 120(3), 253290. doi: $10.2307 / 2343100$.

Grabowski, R., Kraft, S., Pasurka, C., Aly, H. Y. (1990). A ray-homothetic production frontier and efficiency: grain farms in Southern Illinois. European Review of Agricultural Economics, 17(4), 435-448.

Halkos, G., \& Tzeremes. (2010). Performance evaluation using bootstrapping DEA techniques: Evidence from industry ratio analysis. Thessaly, Yunani: University of Thessaly.

Haryanto, T., Talib, B. A., \& Salleh, N. H. M. (2015). An analysis of technical efficiency variation in Indonesian rice farming. Journal of Agricultural Science, 7(9), 144-153.

Kittilertpaisan, J., Kittilertpaisan, K., \& Khatiwat, P. (2016). Technical efficiency of rubber farmers' in Changwat Sakon Nakhon: Stochastic frontier analysis. International Journal of Nakhon Economics and Financial Issues, 6(56), 138-141. 
Krejcie, R. V., \& Morgan, D. W. (1970). Determining sample size for research activities. Educational Psychological Measured, 30, 607-610.

Mailena, L., Shamsudin, M. N., Radam, A., \& Mohamed, Z. (2014). Efficiency of rice farms and its determinants: Application stochastic frontier analysis. Trends in Applied Sciences Research, 9(7), 360-371.

Ray, S. C. (2004). Data envelopment analysis: Theory and techniques for economics and operations research (pp 353). New York: Cambridge University Press.

Simar, L., \& Wilson, P. W. (2007). Estimation and inference in two-stage, semiparametric models of production processes. Journal of econometrics, $136,31-64 . \quad \mathrm{d}$ o i : 10.1016/j.jeconom.2005.07.009.

Tasman, A. (2008). Ekonomi produksi: analisis efisiensi dan produktivitas (pp 444). Jakarta: Chandra Pratama.
Tijani, B. A., Latif, I. A., Shamsudin, M. N., \& Kamarulzaman, N. H. (2017). Does oil palm crop age make technical efficiency difference among smallholders in Peninsular Malaysia. International Journal of Economics, Commerce and management, 3,109135.

Toma, P., Miglietta, P. P., Zurlini, G., Valente, D., \& Petrosillo, I. (2017). A nonparametric bootstrap-data envelopment analysis approach for environmental policy planning and management of agricultural efficiency in EU countries. Ecological Indicators, 83, 132-143. doi: 10.106/j.ecolind.2017.07.049

Wilson, P. W. (2009). Fear 1.12 user's guide. Austin, Texas: Department of Economics, University of Texas. 